\title{
Child-friendly Schools: An Assessment of Secondary Schools
}

\author{
Fatma Çobanoğlu*, Zeynep Ayvaz-Tuncel, Aydan Ordu \\ Faculty of Education, Pamukkale University, Turkey
}

Copyright $\mathrm{O} 2018$ by authors, all rights reserved. Authors agree that this article remains permanently open access under the terms of the Creative Commons Attribution License 4.0 International License

\begin{abstract}
As education has many variables, essential arrangements are required in different areas to enhance its quality. School buildings, environmental arrangements, teaching and learning process, sources and materials, teachers, principals, health and security are the variables of which come to mind first. The concept of 'child-friendly school (CFS)' which was initiated and attempted to actualize by UNICEF's studies, has a nature including all these variables listed above and even more. The current study tires to identify to what extend the teachers, the principals and the secondary school students $\left(5^{\text {th }}\right.$ to $8^{\text {th }}$ grades) perceive their school as child-friendly. The mixed method approach was chosen for the study. The quantitative data was collected with 'Child-Friendly School Scale (CFSS)' developed by the researchers. A total of 54 schools and 4007 students comprise the sample, and the scale was implemented in one class from each grade level chosen randomly. The qualitative data were obtained from the volunteer teachers. Results revealed that the CFS characteristics of the schools changed according to the socioeconomic level of the school, gender of the students and the grade level. It can be suggested to construct a sense of awareness for the child-friendly school concept, to provide the continuity of the arrangements and to make them functional.
\end{abstract}

Keywords Child-friendly School, Child Rights, Child-friendly Learning Environment, Concurrent Triangulation Strategy, Secondary School

\section{Introduction}

Since the adoption of the Convention on the Rights of the Children in many countries, the educators have searched for the ways to realize this convention. One of the best attempts is the child-friendly school action, which adopts a rights-based education approach.

The Convention on the Rights of the Children [5] has strengthened and expanded the idea of education based on human rights with four key principles: (1) Preventing discrimination, (2) Behaving in the best interest of the child, (3) Making the child live and remain at the highest possible level, (4) Allowing the children to express themselves in any situation that affects them. The emphasis here is on the access which creates an opportunity for learning; the quality which supports cognitive and affective development; and the respect which cherishes the individual's language, culture, religion, and perspective. These are the bases of rights-based education and those mentioned above are the significant principles. They paved the way for the search for schools ensuring the overall development of the child and the constructing of a child-friendly approach in the 1990s [24].

Besides being an opportunity for realizing children's rights, a child-friendly school (CFS) has also begun to be adopted as a balance factor against the action of effective schools, which is trying to make a difference on student achievement in many places. This is because the effective school practices, which were firstly aimed to improve the participation of disadvantaged children in society, have started to focus on effectiveness and numbers as a by-product of economic models in national education programs rather than the welfare of children and the quality of education. As a result, many of the educators have begun to be interested in quality and participation in education, and the child's well-being again with CFS practices [2].

\subsection{Child-friendly School}

Regarding the aim of the CFS model, UNICEF [22] suggests that it is intended "to move schools and education systems progressively towards quality standards, addressing all elements that influence the well-being and rights of the child as a learner and the main beneficiary of teaching, while improving other school functions in the process". In this sense, the conceptual framework includes five important principles, which might be used as a starting point to transform the schools into child-friendly ones and to reveal the notion of child-friendly schools [3, $17,22]$.

The first principle named as inclusiveness deals with the issue that schools are suitable for every single child 
based on human rights. Schools are supposed to accept the students applying to them; however, they also have to consider the others who need education. Additionally, the schools are responsible for the acceptance and attendance of all students. Schools include all children: They do not exclude, discriminate or stereotype, and provide an accessible and free education, especially for families and children at risk, respect the differences, and guarantee a learning environment for every child (e.g., girls, working children, children of ethnic minorities, children affected by HIV/AIDS, children with disabilities, and victims of violence).

Another important principle emphasized in The Convention of Children Rights [5] is that member states have the responsibility to provide a safe, healthy and protective environment away from violence, injury, abuse and neglect while guaranteeing that the discipline practices at school are for the sake of the child. Moreover, children should be able to reach best possible health care services. This kind of a learning environment promotes the physical and psychological health of all children. In a CFS, a healthy, hygienic, and safe learning environment, with adequate water and cleaning facilities and healthy classrooms, health policies and practices (e.g., a school free of drugs, corporal punishment, and harassment) are provided as well as the health services such as nutritional supplement and counselling. In addition, these schools provide a health education based on life skills and support the physical and the psycho-socio-emotional health of the teachers and the students.

As another key principle, effectiveness emphasizes quality teaching and learning processes, in which individualized, active, cooperative and democratic learning methods that are suitable for each child's developmental level, ability and learning style are implemented. Quality materials and resources are provided with a constructed content, and the teachers' capacity, morale, commitment, statues, incomes and awareness of child rights are increased. Moreover, children are guided in terms of what and how they should learn, and this leads to quality learning outcomes. Appropriate methods are determined to evaluate the children in class and in national level.

With democratic participation as a fourth principle, the decision-making process related to the school and its environments becomes more effective as it includes the children in the process. In other words, this process is actually a decision-making process, including the child, family, and the society. In this way, children have also a voice in school life; the families as their primary caregivers and the educators cooperate with the child and the teacher, and society plays a role as a shareholder in supporting the child and protecting his/her rights.

Gender responsiveness, which is the last principle of the child-friendly schools, requires that every child have the equal right of education regardless of their gender. An educational environment is provided where there is no gender discrimination for both girls and boys, where students construct healthy relationships and are educated through their needs. With materials and experiences, gender equality is provided for school attendance and achievement, and this perspective is also reflected in the curriculum, course books, and learning\& teaching processes. Moreover, while each student's rights, differences, and equalities are respected, girl-friendly practices are also encouraged.

The concept of child-friendly settings was firstly used by UNICEF in the context of improving engagement areas and later used more for educational settings. Many of the politicians in developing countries have focused on this concept. In last 10 years, these practices were encouraged in primary schools and attempts to transfer child- friendly environments to the schools were made with the UNICEF's "Child-Friendly Schools Manuel" [22]. In this document of UNICEF, the importance of the learning and teaching "quality" is emphasized, and also it is stated that at the focus of all these practices, "as the learner the child stays in the center of learning and teaching process". Moreover, an importance is attributed to the "inspiring" classrooms, pedagogical materials supporting "learning and teaching" and teachers using "interactive child-centered methods that make learning enjoyable and exciting for the students". The model of CFS is an approach which encourages the schools to work for the benefit of the child, in which educated teachers provide a safe, healthy and protective environment; with adequate resources and physical, emotional, and social conditions for learning; protecting children's rights; having a learning context allowing children to learn and develop; respecting the identities, interests and needs of children [23].

This kind of child-friendly environments is thought to increase children's academic achievement and reduce the grade repetition [6]. In other words, schools provided with child-friendly characteristics are predicted to improve the quality and variety of learning outcomes, prevent negative attitudes towards school and learning, and reduce grade repetition and dropout rates.

CFS expresses a comprehensive concept and does not just focus on the effectiveness of the teaching-learning process. "The child has the right to be curious, to ask questions and receive answers, to argue and disagree, to test and to make mistakes, to know or not know, to create and be spontaneous, to be recognized and respected. There should be a sense of recognition in the school of the reality that pupils are individuals and learn in different ways and at a different pace" [11]. In their experimental study, Brendenberg and Heeyit [2] resulted that CFS has a positive effect on metacognitive thinking skills of the students. On the other hand, based on their study conducted in 6 countries, Osher, Kelly, Tolani-Brown, Shors and Chen [18] stated that teachers lacked adequate qualities to implement the CFS approach, and also they did not get a required education to implement CFS. Modipane and Themane [15] pointed out the usage of 
CFS in curriculum development and teacher training processes to provide its sustainability.

Clair, Miske and Patel [3] think that CFS is a promising model for educational reforms and in this way, governments can promote the child right in many ways. Similarly, because of his study, Orkodashvili [17] stated that child-friendly systems can form a normative goal for both a qualitative education and the protection of the child rights. In this sense, practices aiming to ensure schools have child-friendly features have increasingly appeared as a basis for educational policies in recent years. In Turkey, CFS studies were initiated with the cooperation of the Ministry of National Education and UNICEF in the 2003-2004 academic year, and the components for making a school child-friendly have taken place in "Institutional Standards Regulation" as well. In spite of all these regulations, schools are required to be examined in terms of how far they are child-friendly. Reimer [27] emphasized that cultural values of the society is a more important factor on the legal regulations in realizing the global goals of the CFS approach locally. To identify to what extent the schools in Turkey are child-friendly in this study is significant for the functionality of legal regulations in real life. Furthermore, no any other research result was found about CFS practices in Turkey, and this makes the current study more significant. Consequently, in this study, it is aimed to investigate the situation of secondary schools' being child-friendly in Denizli city center according to the views of principals, teachers, and students.

\section{Method}

\subsection{Research Design}

In this research, the mixed model approach comprising quantitative and qualitative research methods was employed. The quantitative method makes possible to consult more people's views. In the meantime, with the qualitative study, more detailed information can be acquired. As both qualitative and quantitative data were gathered simultaneously, "Concurrent triangulation strategy" suggested by Creswell [4] was used.

\subsection{Participants}

The quantitative data of the study were gathered from the secondary schools in Denizli city center. Firstly, 63 schools were divided into three groups as low, moderate and high in terms of their observed socioeconomic level via the views of school supervisors. Then, the schools included in the study were determined using proportional cluster sampling method for each group. A total of 54 schools and 4007 students were included in the sample and just one class from each grade level was selected randomly. Table 1 shows the distribution of the participants with respect to the variables of socioeconomic level, grade, and gender.
Table 1. Distribution the participants according to socioeconomic level, grade, and gender

\begin{tabular}{|c|c|c|c|}
\hline & & Frequency & Percent \\
\hline \multirow{4}{*}{ Socio-economic level } & Low & 1760 & 43,9 \\
\cline { 2 - 4 } & Moderate & 1347 & 33,6 \\
\cline { 2 - 4 } & High & 900 & 22,5 \\
\hline \multirow{4}{*}{ Grade } & 5 th & 1045 & 26,1 \\
\cline { 2 - 4 } & 6th & 958 & 23,9 \\
\cline { 2 - 4 } & 7 th & 977 & 24,4 \\
\cline { 2 - 4 } & 8 th & 1027 & 25,6 \\
\hline \multirow{3}{*}{ Gender } & Girl & 2052 & 51,2 \\
\cline { 2 - 4 } & Boy & 1955 & 48,8 \\
\hline
\end{tabular}

The qualitative data of the study were obtained from the volunteer teachers $(n=18)$ and principals $(n=6)$ working at the schools where the instrument was administered.

\subsection{Data Tools and Procedure}

As a three-point $(1=$ not agree, $2=$ partly agree, $3=$ agree) Likert type scale, "Child-Friendly School Scale (CFSS)," developed by the researchers was used as the quantitative data collection tool for the study. A pilot study was conducted with the 54-item scale and the Cronbach alpha coefficient was found to be 896 . Four negative items under .20 were removed after examining the item-total correlation. As a result, the Cronbach alpha coefficients were found to be .90 for the scale, and between .64 and .81 for the dimensions.

The exploratory factor analysis (EFA) was conducted to 400 students using Varimax rotation method. Before the analysis, Kaiser-Meyer- Olkin KMO) and Bartlett test was examined and found to be acceptable for the EFA (KMO $=.867$ ). Ten items having close values under two separate factors and four items loading under irrelated factors were removed from the scale. Results showed a 36-item scale with 4 factors explaining $35 \%$ of the total variance. The dimensions of the scale were labelled as effectiveness and inclusiveness (15 items), protective precautions and participation ( 9 items), health and security (6 items), and management of the relations (6 items). To test the factor structure of the scale, confirmatory factor analysis (CFA) was conducted to 400 students out of the pilot study. The goodness of fit indices were found to be $x^{2}(588)=918.64$, $\mathrm{P}=.00,\left(x^{2} / \mathrm{sd}\right)=1.56, \mathrm{RMSEA}=.037, \mathrm{NNFI}=.96, \mathrm{CFI}=.97$, $\mathrm{SRMR}=.049$ and $\mathrm{GFI}=.89$. As a result, four-factor scale structure was confirmed by the analysis.

A CFA has been conducted again to the collected data and results confirmed the for-scale structure with adequate fit indices. $\left(x^{2}(585)=3144.02, \mathrm{P}=.00,\left(x^{2} / \mathrm{sd}\right)=5.37\right.$, RMSEA $=.037, \mathrm{NNFI}=.97, \mathrm{CFI}=.97, \mathrm{SRMR}=.033$ and $\mathrm{GFI}=.95$ ). Because of the sensitivity of $x^{2}$ value to the sample size $(n=4007)$, its value was found to high. However, considering the goodness of fit indices, the scale structure can be accepted as valid.

Furthermore, interview questions related to the literature on the CFS were prepared. Organized after the views of experts, the open-ended interview form includes 11 
questions. Considering the dimensions of the CFS, some examples from the interview form as below: "What are the actions related to the security of yourself and your students in the school?", "What is the attitude of school management towards participating in decisions (teacher, parent, student)?", "What are the arrangements related to the individual differences of students in courses?"

\subsection{Data Analysis}

SPSS 17.00 was used for the data analysis. Skewness and kurtosis were calculated as -.46 and -.52 respectively. Besides, Q-Q Plot and Histogram graphics were examined and normal distribution was observed for the data. The condition of whether the schools are child-friendly was examined with parametric tests (descriptive statistics, t-test, one-way ANOVA and Tukey HSD).

Students' perception of their school's having child-friendly school characteristics were classified as a low, moderate and high level. In calculating the intervals between the values related to these levels, the minimum point is subtracted from the maximum point, which can be gathered from the related dimension, and the result is divided by three. In Table 2, intervals were presented.

Table 2. Intervals of factor levels

\begin{tabular}{|c|c|c|c|}
\hline Factor & Low & Moderate & High \\
\hline Effectiveness and Inclusiveness & $15,00-25,00$ & $25,01-35,00$ & $35,01-45,00$ \\
\hline Protective Precaution and Participation & $9,00-15,00$ & $15,01-21,00$ & $21,01-27,00$ \\
\hline Health and Security & $6,00-10,00$ & $10,01-14,00$ & $14,01-18,00$ \\
\hline Management of the Relations & $6,00-10,00$ & $10,01-14,00$ & $14,01-18,00$ \\
\hline
\end{tabular}

The qualitative data set was coded and the themes were obtained via content analysis. Interrater reliability coefficient is calculated as $95.4 \%$. The findings of quantitative and qualitative data were presented in an integrated way as a requirement of the concurrent triangulation strategy.

\section{Findings}

\subsection{Effectiveness and Inclusiveness}

Table 3 presents how the students perceive their schools related to the effectiveness and inclusiveness dimension.

Table 3. Students' perceptions related to the dimension of effectiveness and inclusiveness.

\begin{tabular}{|c|c|c|c|c|c|c|}
\hline & $\mathrm{N}$ & Min. & Max. & Mean & Std. Deviation & CFS Level \\
\hline Effectiveness and inclusiveness & 4007 & 15 & 45 & 36,46 & 5,18 & High \\
\hline
\end{tabular}

When students' responses to the statements in the dimension of effectiveness and inclusiveness are examined, although it seems to be near to the moderate level, students perceived their schools as child-friendly at high levels. The teachers and the principals' views on the effectiveness and inclusiveness are presented in Table 4.

Table 4. Teacher and principal views on the dimension of effectiveness and inclusiveness

\begin{tabular}{|c|c|c|}
\hline Effectiveness and Inclusiveness Themes & Teachers' codes (f) & Principals' codes $(f)$ \\
\hline Active participation of students & $\begin{array}{c}\text { Establishing a Positive Communication(19) } \\
\text { Using various methods and techniques (14) } \\
\text { Extracting activities(13) } \\
\text { Using rewards and reinforcement (12) } \\
\text { Using material (4) } \\
\text { Associating with daily life (4) }\end{array}$ & $\begin{array}{l}\text { Using rewards and reinforcement (5) } \\
\text { Using material (3) } \\
\text { Projects (3) } \\
\text { Establishing a Positive Communication (2) } \\
\text { Using various methods and techniques (1) }\end{array}$ \\
\hline Material sufficiency and supply & $\begin{array}{c}\text { Legal Supply (13) } \\
\text { Insufficiency of Material (9) } \\
\text { Personal Supply (6) } \\
\text { Sufficient Material (5) }\end{array}$ & $\begin{array}{c}\text { Personal Supply (6) } \\
\text { Sufficient Material (4) } \\
\text { Insufficiency of Material (2) } \\
\text { Legal Supply (1) }\end{array}$ \\
\hline Considering individual differences & $\begin{array}{l}\text { Organizing extracurricular activities ( } 18) \\
\text { Considering interests and skills (13) } \\
\text { Arrangements suitable for learning levels (9) }\end{array}$ & $\begin{array}{c}\text { Organizing extracurricular activities (30) } \\
\text { Providing physical facilities towards individual } \\
\text { differences (7) } \\
\text { Arrangements suitable for learning levels (6) } \\
\text { Considering interests and skills (5) }\end{array}$ \\
\hline Inclusive students & $\begin{array}{c}\text { Preparing Individualized Education } \\
\text { Programs(IEP) (16) } \\
\text { Teacher effort to apply (IEP) (3) } \\
\text { Not being able to apply (IEP) completely (2) }\end{array}$ & $\begin{array}{c}\text { Support to prepare (IEP) (6) } \\
\text { Preparing(IEP) (5) } \\
\text { Teacher effort to apply (IEP) (4) }\end{array}$ \\
\hline
\end{tabular}


As shown in Table 4, the dimension of "effectiveness and inclusiveness" comprises four themes: students' active participation, material sufficiency and supply, considering individual differences and inclusive students. Examining the codes under the theme of active participation of the students, the most emphasized characteristics by the teachers was establishing a positive communication. T14 stated, "..I'm interested in them [the students] personally or call them, for instance, some students do not raise hands. But somehow I communicate with them and try to motivate them.." As for the principals, the most emphasized characteristics were using rewards and reinforcements. P3 stated, “...we invite our students with their parents who are successful in either national exams or in the courses, both at the end of the first and second semester, and give their rewards in front of the other students. So the others aspire and make an effort to get the same thing or rewarded. We try to motivate them as so."

The teachers and the principals do not have an agreement on the issues about material sufficiency and supply which is another theme under the dimension of effectiveness and exclusiveness. Many of the teachers stated that they try to get the required materials by informing their principals in legal ways, while most of the principals stated they try to do this via their personal opportunities. This is what T5 indicated about the legal supply; "..We present an official report to the school management. We say we lack this and that, and when the school opens in September, the materials are already supplied by that time." P4 pointed out personal supply with his statement; ".. We do not collect money from the students. We do not get any support either from the government or from the people. Some benefactors visit us, drink tea or coffee or we visit them to mention our problems. Thanks to them, they do not refuse us and provide our needs, I mean most of our needs..".

Under the theme of "considering the individual differences", teachers and principals mostly pointed out the extracurricular activities organized for individual differences. T11 stated "... for example elective courses, now in elective courses ... physical education teachers are organizing football or volleyball tournaments. Turkish language teachers are arranging Chinese whispers contest or similar knowledge contests... our art teacher is organizing exhibitions all the time displaying the paintings about the subject he has taught before. Our technology and design teacher is also doing the same. Experiments in science elective courses are displayed in the halls, for example, students are doing that experiment and explaining it. And it seems like there is such a science festival ...". P2 points out "...there are extracurricular courses in our school, for example. We have weekend courses. For example, we have volleyball, soccer, or basketball tournaments, both for the young and the adults. There are chess and swimming courses... Then, for example, extra poetry contests held in the city and national composition contests... Projects are made. For example, last year a project was made about Pi day... At the end of the year, there was a theatre day. We are organizing extracurricular activities like these."

Lastly, the "inclusion" theme takes place under the dimension of "effectiveness and inclusiveness". Regarding the inclusion, while the teachers drew attention to the preparation of Individualized Education Program (IEP) the principals underlined their support to this preparation. T15 expressed his opinions on this subject as ".... a am preparing the annual plan and making one-to-one interviews ...". P3 stated that they supported this process; "... our teachers are taking those students to the IEP room within the framework of a plan and a program that we have prepared to provide a better education. They deal with them privately with specially-designed materials as those students have difficulty in comprehension. We also direct them to the counselling service ..."

The teacher has an important role in ensuring effectiveness and inclusiveness. The personal development and motivation of the teacher will indirectly contribute to the process to be effective and extensive. From the interviews, the data regarding teachers' motivation sources and their personal development were also obtained.

Table 5. Teacher and principal views about teachers' motivation sources and personal development

\begin{tabular}{|c|c|c|}
\hline Themes & Teacher's codes & Principal's codes \\
\hline & Social activities (18) & Positive Communication (12) \\
Social activities (11) \\
Increasing the motivation & Cooperation (12) & Appreciation and rewarding (3) \\
& Cooperation (1) \\
\hline \multirow{2}{*}{ Personal development } & Attitude of the administration (5) & Intrinsic motivation (3) \\
& Children's eagerness and awareness (1) & In-service training (4) \\
& In-service training (14) & Administrative Support (3) \\
\hline
\end{tabular}

Teachers mentioned mostly about the social activities organized and cooperation with their colleagues for increasing the motivation. T6 expressed his views as "... We do it at the end of the term and we do it at the end of the year. We have breakfast organizations at the beginning of the term. We attend dinner or breakfast programs in unity as much as we can. ". The principals, on the other hand, stated that besides the social activities, they take the advantage of positive communication to improve the teachers' motivation. On this subject, P5 expressed his views as "I am trying to regard 
what we call management from a different perspective, I mean anybody does not refer "the principal" as someone to escape from. I greet everyone, ask their mood, and make jokes to please them... ".

Under "the personal development" theme, the teachers and the principals emphasized the in-service training and administrative support. In this respect, T12 said "...there are trainings you know, and the seminars given by the national ministry of education. We participate in them regularly ..."

\subsection{Protective Precaution and Participation}

Student responses towards the statements in the dimension of Protective Precaution and Participation of CFSS are presented in Table 6 .

Table 6. Students' perception regarding the dimension of protective precaution and participation

\begin{tabular}{|c|c|c|c|c|c|c|}
\hline & N & Min. & Max. & Mean & Std. Deviation & CFS Level \\
\hline Protective precaution and participation & 4007 & 9 & 27 & 21,48 & 3,39 & High \\
\hline
\end{tabular}

The data revealed that students perceived their schools child-friendly in a high level in terms of protective precautions for health and safety and participation of the stakeholders. Teacher and principal perceptions for the dimension of Protective Precaution and Participation are presented in Table 7.

Table 7. Teacher and principal perceptions regarding the dimension of Protective Precaution and Participation

\begin{tabular}{|c|c|c|}
\hline $\begin{array}{c}\text { Protective precaution and participation } \\
\text { themes }\end{array}$ & Teacher's codes & Principal's codes \\
\hline & Teacher participation in decision-making (15) & Teacher participation in decision-making (8) \\
& Parent participation in decision-making (11) & $\begin{array}{c}\text { Students' participation in decision-making (6) } \\
\text { Parent participation in decision-making (4) } \\
\text { Indifference of parent (4) }\end{array}$ \\
& $\begin{array}{c}\text { Student participation only on paper (9) } \\
\text { Indifference of parent (8) }\end{array}$ & Not Establishing student participation (2) \\
\hline Precautions & Students' participation in decision-making (4) & Informing (10) \\
\hline
\end{tabular}

The dimension of protective precaution and participation was handled with two themes named as "democratic participation" and "precautions". As can be seen in Table 7, when democratic participation is analysed, the code that was emphasized most by both teachers and principals is the teacher's participation in decision-making. The expression of T13, "We express our opinions in the meetings held at the beginning and end of the year, or we are always in sessions and talk during break times. If these ideas are already applicable, our principal considers them in any way and tries to implement them", reflects this. All of the principals that were interviewed stated that they included teachers in the decision-making process most of the time or all the time. P5 expressed his ideas stating, "I am a person who likes to consult. We have a proverb meaning two heads are better than one. From my own perspective, something can be true but it is possible that another point of view is also true. That's why I ask my colleagues...I usually consult with them. Yet there are things that cannot be consulted about legal issues ... no need to consult and it is just required to be done."

About the protective precautions, only two teachers stated that they ventilate the classroom while the principals mention that they just inform about the issue. P4 asserted, "Teachers give seminars at least three or four times a year. Except for this, we try to raise students' awareness to be clean with the aim of protecting their health in every chance like things that we do one-to-one in terms of health, or in classes or in ceremonies. For example, we ask them to put the rubbish into the bins."

\subsection{Health and Security}

Student responses towards the statements in the dimension of Health and Security are presented in Table 8.

Table 8. Students' perception according to the dimension of health and security

\begin{tabular}{|l|c|c|c|c|c|c|}
\hline & $\mathrm{N}$ & Min. & Max. & Mean & Std. Deviation & CFS Level \\
\hline Health and security & 4007 & 6 & 18 & 13,43 & 2,17 & Moderate \\
\hline
\end{tabular}

The data demonstrated that students perceived their schools child-friendly in a moderate level in terms of Health and Security. Teacher and principal views on the dimension of Health and Security are presented in Table 9 below. 
Table 9. Teacher and principal views on the dimension Health and Security

\begin{tabular}{|c|c|c|}
\hline Health and security themes & Teacher codes & Principal codes \\
\hline & Daily School and Class Cleaning ( 16) \\
& Vaccination and Screening (10) & \\
& Hygiene of canteen (8) & Daily School and Class Cleaning (9) \\
Protection of health & Hygiene of toilet (5) & General yearly cleaning (4) \\
& First aid cabinet (3) & First aid cabinet (4) \\
& Teacher's individual effort (3) & Hygiene of canteen (4) \\
& Garden cleaning by students (3) & \\
\hline Providing security & General yearly cleaning (2) & Physical Arrangements (11) \\
& Hall monitoring by teacher and student (18) & Hall monitoring by teacher and student (9) \\
& Physical Arrangements (9) & Security Guard (3) \\
& Caution signs (2) \\
& Security Guard (7) & Undercover policeman (3) \\
& Informing parents (2)
\end{tabular}

As another dimension of the study, health and security was handled with two themes as "protection of health" and "providing security". Both teachers and the principles draw attention most to the issue that school and classroom cleaning is conducted daily. In addition, another point that is emphasized by both of the groups is vaccination and screening. About daily school and classroom cleaning, T11 reflected her ideas saying, "Our school gives great importance to cleaning. As soon as morning groups leave school, classes are cleaned immediately, corridors are wiped, and the janitors continue working all the time during breaks. The cleanliness of the class and school is of crucial importance to us as a kind of precaution to illnesses." In the theme of providing security, most of the teachers mention the role of hall monitoring by the teachers and the students in order to maintain security. T11 comments on the issue saying that "for students' safety hall monitoring teachers are aware of their responsibilities and they hardly ever leave their places during all day... hall monitoring students already watch the gates for security..." Principals, on the other hand, emphasize the physical arrangements. P3 alleged that "We especially keep the windows under control, for ventilation, we leave the windows open from the top, that is, physically we have nothing posing a danger."

\subsection{Management of Relations}

Student responses towards the statements in the dimension Management of Relations are presented below in Table 10.

Table 10. Students' perception of the management of relations

\begin{tabular}{|l|c|c|c|c|c|c|}
\hline & $\mathrm{N}$ & Min. & Max. & Mean & Std. Deviation & CFS Level \\
\hline Management of relations & 4007 & 6 & 18 & 14,10 & 2,31 & High \\
\hline
\end{tabular}

Students highly perceived their schools child-friendly in regard to the management of relations, even though the obtained score was very close to the moderate level interval. Teacher and principal views on the dimension of management of relations are presented in Table 11.

Table 11. Teacher and principal opinions on the dimension of management of relations

\begin{tabular}{|c|c|c|}
\hline Themes & Teacher's codes & Principal's codes \\
\hline Gender discrimination & $\begin{array}{c}\text { Non-discrimination (15) } \\
\text { Regarding the female students as more responsible (4) }\end{array}$ & $\begin{array}{c}\text { Non-discrimination (7) } \\
\text { Regarding the female students as more responsible (2) }\end{array}$ \\
\hline
\end{tabular}

As can be seen in Table 11, the dimension of the management of relations consists of just one theme. About this theme, the teachers and the principals say that they do not do any discrimination, but they believe that girls are more responsible. T3 said he doesn't do any discrimination stating "even today the board wasn't cleaned, the table was messy and I made a joke and said I am surprised about the girls of this class, I think in this case they are not clean enough. Moreover, one student in the class answered: "teacher, are these done by girls?" Mmmm, (I answered) I have told this intentionally. Yes, boys should also do these things. Whoever it is, the responsible person of the class that day should have done these things and ensured the order of the class. From now on there is nothing like that: This job is a girl's job and that one is a boy's job". T15 also finds girls more responsible arguing, "Girls are better at providing neatness and fulfilling their responsibilities, I believe this is so because of special upbringing by the families. I mean they were given more tasks or responsibilities in terms of neatness while being brought up. In this sense, boys are one step back; we have just a few exceptions, so mainly girls are better."

The second question of the study concerns whether the students' perceptions differed significantly based on their schools' socioeconomic level, gender, and grade. Table 12 presents the analysis results below. 
Table 12. Comparison of the students' perceptions of child-friendly schools in terms of socio-economic levels

\begin{tabular}{|c|c|c|c|c|c|c|c|}
\hline & S. economic level & $\mathrm{N}$ & Mean & Std. Deviation & $\mathrm{F}$ & $\mathrm{p}$ & Dif \\
\hline \multirow{3}{*}{$\begin{array}{l}\text { Effectiveness and } \\
\text { inclusiveness }\end{array}$} & Low & 1760 & 37,0 & 4,95 & \multirow{3}{*}{22,2} & \multirow{3}{*}{, $000 * *$} & $1-2$ \\
\hline & Moderate & 1347 & 36,0 & 5,38 & & & $1-3$ \\
\hline & High & 900 & 35,9 & 5,19 & & & \\
\hline \multirow{3}{*}{$\begin{array}{c}\text { Protective precaution and } \\
\text { participation }\end{array}$} & Low & 1760 & 22,0 & 3,21 & \multirow{3}{*}{49,8} & \multirow{3}{*}{, $000 * *$} & $1-2$ \\
\hline & Moderate & 1347 & 21,3 & 3,42 & & & $2-3$ \\
\hline & High & 900 & 20,7 & 3,50 & & & $1-3$ \\
\hline \multirow{3}{*}{ Health and security } & Low & 1760 & 13,7 & 2,11 & \multirow{3}{*}{18,6} & \multirow{3}{*}{, $000 * *$} & $1-2$ \\
\hline & Moderate & 1347 & 13,2 & 2,17 & & & $1-3$ \\
\hline & High & 900 & 13,3 & 2,24 & & & \\
\hline \multirow{3}{*}{ Management of Relations } & Low & 1760 & 13,9 & 2,29 & \multirow{3}{*}{11,5} & \multirow{3}{*}{, $000 * *$} & $1-3$ \\
\hline & Moderate & 1347 & 14,1 & 2,40 & & & $2-3$ \\
\hline & High & 900 & 14,4 & 2,18 & & & \\
\hline \multirow{3}{*}{$C F S$} & Low & 1760 & 86,7 & 9,62 & \multirow{3}{*}{24,1} & \multirow{3}{*}{, $000 * *$} & $1-2$ \\
\hline & Moderate & 1347 & 84,6 & 10,53 & & & $1-3$ \\
\hline & High & 900 & 84,3 & 10,33 & & & \\
\hline
\end{tabular}

Findings in Table 12 demonstrated that students' perception about how far child-friendly their schools are differed based on the socio-economic status of the school. In other words, schools' child-friendly characteristics change depending on the socio-economic status of the students. When the mean scores were examined, it was seen that schools with the highest scores have a low socioeconomic status; and findings also revealed that perceptions in regard to child-friendly characteristics of the schools increase as the socioeconomic characteristics of students decrease.

Table 13. Comparison of the students' perceptions about in what degree their schools are child-friendly in terms of grades

\begin{tabular}{|c|c|c|c|c|c|c|c|}
\hline & Grade & $\mathrm{N}$ & Mean & Std. Deviation & $\mathrm{F}$ & $\mathrm{p}$ & Difference \\
\hline \multirow{4}{*}{ Effectiveness and inclusiveness } & 5 th & 1045 & 38,4 & 4,66 & \multirow{4}{*}{99,09} & \multirow{4}{*}{, $000 * *$} & $5-67-8$ \\
\hline & 6th & 958 & 36,8 & 4,76 & & & $5-7$ \\
\hline & 7 th & 977 & 35,7 & 5,13 & & & $5-8$ \\
\hline & 8 th & 1027 & 34,8 & 5,40 & & & $6-7$ \\
\hline \multirow{4}{*}{$\begin{array}{c}\text { Protective precaution and } \\
\text { participation }\end{array}$} & 5 th & 1045 & 22,2 & 3,22 & \multirow{4}{*}{35,15} & \multirow{4}{*}{, $000 * *$} & $5-67-8$ \\
\hline & 6th & 958 & 21,7 & 3,35 & & & $5-7$ \\
\hline & 7 th & 977 & 21,3 & 3,25 & & & $5-8$ \\
\hline & 8 th & 1027 & 20,7 & 3,54 & & & $6-7$ \\
\hline \multirow{4}{*}{ Health and security } & 5 th & 1045 & 13,9 & 2,07 & \multirow{4}{*}{38,00} & \multirow{4}{*}{, $000 * *$} & $5-67-8$ \\
\hline & 6 th & 958 & 13,4 & 2,10 & & & $5-7$ \\
\hline & 7th & 977 & 13,7 & 2,21 & & & $5-8$ \\
\hline & 8 th & 1027 & 13,0 & 2,18 & & & \\
\hline \multirow{4}{*}{ Management of relations } & 5 th & 1045 & 14,4 & 2,40 & \multirow{4}{*}{7,038} & \multirow{4}{*}{, $000 * *$} & $5-8$ \\
\hline & 6th & 958 & 14,1 & 2,20 & & & $5-7$ \\
\hline & 7th & 977 & 14,0 & 2,27 & & & \\
\hline & 8th & 1027 & 13,9 & 2,33 & & & \\
\hline \multirow{4}{*}{$C F S$} & 5 th & 1045 & 88,9 & 9,42 & \multirow{4}{*}{80,78} & \multirow{4}{*}{, $000 * *$} & $5-67-8$ \\
\hline & 6th & 958 & 86,1 & 9,47 & & & $5-7$ \\
\hline & 7th & 977 & 84,3 & 9,88 & & & $5-8$ \\
\hline & 8th & 1027 & 82,5 & 10,62 & & & $6-7$ \\
\hline
\end{tabular}

Table 13 indicates that students' perception of their school's child-friendly characteristics differed based on their grades. 
Examining the mean scores, the highest scores belong to the fifth graders. As the grade level increases, the perception of being child-friendly decreases.

Table 14. Comparison of the students' perceptions of child-friendly schools in terms of gender

\begin{tabular}{|c|c|c|c|c|c|c|}
\hline & Gender & $\mathrm{N}$ & Mean & Std. Deviation & $\mathrm{t}$ & $\mathrm{p}$ \\
\hline \multirow{2}{*}{ Effectiveness and inclusiveness } & Girl & 2052 & 36,94 & 5,10 & 6,013 &, $000 * *$ \\
\hline & Boy & 1955 & 35,95 & 5,22 & & \\
\hline \multirow{2}{*}{ Protective precaution and participation } & Girl & 2052 & 21,90 & 3,20 & 8,202 &, $000 * *$ \\
\hline & Boy & 1955 & 21,03 & 3,51 & & \\
\hline \multirow{2}{*}{ Health and security } & Girl & 2052 & 13,58 & 2,10 & 4,694 &, $000^{* *}$ \\
\hline & Boy & 1955 & 13,26 & 2,23 & & \\
\hline \multirow{2}{*}{$\begin{array}{c}\text { Management } \\
\text { of relations }\end{array}$} & Girl & 2052 & 14,60 & 2,02 & 14,335 &, $000 * *$ \\
\hline & Boy & 1955 & 13,58 & 2,47 & & \\
\hline \multirow{2}{*}{ CFS } & Girl & 2052 & 87,04 & 9,65 & 10,078 &, $000^{* *}$ \\
\hline & Boy & 1955 & 83,84 & 10,41 & & \\
\hline
\end{tabular}

Table 14 demonstrates that students' perception of how child-friendly their schools are differed according to their genders. Considering the mean scores, girls described their schools more child-friendly compared to the boys.

\section{Discussion and Conclusions}

The child-friendly school is a concept that includes variables such as school buildings, environmental arrangements, teaching-learning process, sources and materials, the teacher, principals, health, security, democratic participation and gender sensitivity. All these variables have the strength of affecting educational quality either directly or indirectly. Examining the related literature, no research has been found on "child-friendly school" including all these variables together. However, there are separate studies about the variables of CFS (Nutrition Friendly Schools Program, White Flag Project Democracy Zone Project, School Milk Project, etc.). In this research, which has examined all these variables, schools were perceived to be child-friendly at high levels by their students.

The effectiveness and inclusiveness of the schools are high according to the students' perceptions. Teachers also indicated that they made efforts to increase the effectiveness and inclusiveness throughout the process. However, as the total score is near the sub-limit of high level, our schools might be concluded not to have all the child-friendly characteristics expected in this dimension. It is stated in the report of UNICEF that although most of the teachers adopt the principles of child-centered pedagogies, they fail to satisfy a child-friendly school environment with their pedagogical approaches [18]. It is important to consider the individual differences and make necessary changes especially to provide the effectiveness and inclusiveness. Behaviours like paying more attention to the slow learners; realizing the problems about the lesson and helping them; knowing how each student learns better and asking about the issues that the students wonder seem not to be performed often enough. According to DuFour, DuFour, Eaker and Karhanek [2004 cited in 12], if students need extra time to acquire some skills, the schools should develop the necessary strategies to supply those students with the time they need within the school day. If all the students are expected to have the same academic standards, all of them need to have the learning conditions they need in order to have those standards.

The teachers and the principals underlined the extracurricular activities in terms of individual differences, and it is a handicap for an effective and comprehensive teaching-learning process. This situation may be because the teachers do not have the necessary information about the regulation of the process, besides the classes are crowded and the teachers do not have enough time to get to know each individual student. UNICEF also emphasized that the CFS trainings for the teachers are not sufficient and the teachers cannot gain enough skills to implement the child-centered techniques [18]. There are many trainings, seminars, and workshops conducted by Turkish National Ministry of Education to overcome the deficiencies of the teachers and to motivate them. Still, apart from these legal trainings, teachers do not seem to make any personal effort for their individual development. This might be rooted in teachers' not having enough awareness about CFS and in turn, they do not feel any need for their development.

While the students perceive their schools to be at the high level in terms of protective precautions and participation, it is striking that the schools are actually at the moderate level limits. Considering the items related to protective precautions, teachers warn the students about ventilating the classes which in fact a situation they are also annoyed. Furthermore, it is understood that the principal performs various training, drills, and preparations that take place in the regulations, and girls and boys give required importance to be respectful to each other. Findings also 
indicate that students do not get enough support from their teachers and school for growing up healthily, protection from illnesses and dangers outside the school. The sanitation issues seem to be left to the administration because only two teachers said that they warn the students about airing the classes.

When the items related to the participation are analysed, even if the students stated that their teachers are not eager to meet their parents, the school administration interact with the parents at a necessary level concerning the students' participation and attendance to the school. In the interviews, teachers and the principals underlined the careless parents. This conflict between the views of students and teachers and principals might be because of the unclear expectations and communication gaps. In spite of this, Redding states that the parent-teacher interaction is useful for both academic success and behavioural concerns [21]. However, according to Dodson [8], Yiğit and Bayrakdar [25], Osher et al. [18] and Nyatuka [16], some situations like not being able to find time from work and home, the negative school experiences of parents, economic problems, low levels of education, teachers' negative attitudes, and the cultural differences between the school and the home prevent the parental involvement and the cooperation.

Considering the teachers' views on participation, it is seen that the school councils formed through legal regulations are only in theory. However, as also stated in the child rights agreement, it is one of the basic rights of the children to get engaged in the decisions affecting themselves. Kılıç [14] and Değirmencioğlu [7] also stated that the school councils do not function as they are expected to.

The items within this dimension; not attending extracurricular school activities in a sufficient amount and not providing the students with the necessary environment to be informed and to discuss the equality of men and women are perceived at a low level by the students. This situation might be because of the perspective of the society concerning the gender equality, and because of the teachers' self-efficacy beliefs in conducting such a discussion as well. According to Commeyras (1997, cited in [10], teachers are not comfortable with the gender-related discriminative expressions' being discussed in the classes, women and men descriptions in the books, and male and female students' asking questions to describe their own genders.

Within the context of child-friendly school features, the students perceive their schools at a moderate level in terms of the 'health and security' dimension. Examining the items, the students feel safe in the school and on the way to home from school. UNICEF evaluation report also indicates most of the students feel safe at their school [18]. However, such issues stated by the students as the class temperature's not being at a suitable level all the time, the toilets' not being cleaned regularly, the breaks' not being long enough for eating, and the students' choosing a place outside instead of the school cafeteria for eating may cause health and security problems. Erol [9] also found out the secondary school students think that the toilets are not clean enough. According to the data from the interviews, the teachers and the principals seem to emphasize the daily cleaning of the schools and the classrooms, vaccination and health screenings. It can be concluded that except for the routine implementations for protecting health, the preventive health services are not carried out sufficiently. This may also refer to the teachers and principals' sense of health. Being healthy does not only mean not being ill or crippled but also a condition of physical, psychological, and social well-being. A school health is all the activities, services and strategies at schools or related to schools, which are implemented to support the physical, psychological and social development of the students [19]. Özcebe [20] states that there is a linear relationship between the health of the child and the efficiency of the institution and that a fall in academic success causes behaviours that threaten health.

Students feel safe at school. The teachers and the principals also stated that the security is provided through the physical regulations at the school and the hall monitor teacher \& student applications. Alver, Adıgüzel and Öztürk [1] also found out that the students and teachers in $5^{\text {th }}-12^{\text {th }}$ grades feel safe in state schools. However, examining the response to the other items of security dimension, schools have some security deficiencies. Especially the students' trying to access their needs not from the school cafeteria but from outside within the school time is a serious security problem.

It is striking that while the students perceive their schools as high-level child-friendly in terms of the management of relationships, it is actually very close to the moderate level limit. When the items in the scale are analysed, it can be said that generally, teachers do not have negative attitudes during the in-class communications and that they avoid the implementations focusing on societal gender roles. However, it is understood that the students do not have equal right to speak during the classes. It is also seen in the interviews that the teachers and the principals do not make any gender related discriminations but they find the female students more responsible. This might be rooted in the social roles attributed to genders. In a research of Reimer [27] it is emphasized that despite the arrangements of CFS, cultural values are important to perceive the gender roles. According to Gray\&Leith [10], in accordance with the claims that girls have higher working standards and that they are more honest; girls are more meticulous, on the contrary to boys, girls are motivated more by their teachers, have better behaviours and expect less attention.

It is seen that gender has an effect on the child-friendly school perception and that the male students perceive their schools as having less child-friendly properties. Similarly, UNICEF's report outlined that boys feel less safe in their 
schools [18]. It can be said that the teacher behaviours and gender-based communication styles are effective in this perception. Younger and Warrington [26], claim that while the male students are disciplined more than females, it is sometimes difficult to decide whether they actually deserve the punishments. The current worries about the male students' failure make it necessary to focus more on the gender issues in teacher training [10].

Findings also revealed that the socio-economical level is effective on the child-friendly school perception. It is striking that, as the socio-economical level increases, the students perceive their schools less child-friendly. The reason for this can be the increase in the expectations in accordance with the opportunities owned. Furthermore, as the children grow older, their perception of being child-friendly decreased. This situation may be the result of the school environment's not being regulated according to all students' needs. According to the research by Kahveci and Demirtaş [13], it was also found out that the perception of the school facilities decreases as the class grade increases. Nevertheless, in UNICEF's evaluation report, students feel safer as their grade level increases [18].

Making schools child-friendly is not an "all-or-nothing" process [22]. This requires a long-term study. Instead of trying to change all features at once, it can be tried to start with one and pass to others in time. The important thing here is the effort made by the teacher, the principals, and the parents collaboratively in order to make the schools child-friendly in a determined way. Within this concern, these suggestions are presented;

- Firstly, increasing the feeling of need and awareness of the stakeholders on child-friendly school,

- Taking the student gender, characteristics and expectations into account while the physical regulations of the schools are prepared,

- Putting the regulations about the democratic involvement of the stakeholders in practice,

- Providing the sustainability of the projects (Nutrition Friendly School, White Flag Project, Democracy Zone Project, School Milk Project, Promoting Gender Equality in Education Project etc.) started by UNICEF, European Union, The Ministry of Health and Ministry of Education, analysing their results and making them functional.

- Ensuring the teachers' being knowledgeable about the child-friendly school and its variables through the pre-service and in-service training, and

- Making similar studies at different school levels and in different environments.

\section{Acknowledgements}

This study was supported as a Research Project (project no: 2016HZDP011) by Pamukkale University and presented as an oral presentation at $2017 \mathrm{IV}$. International Eurasian Educational Research Congress at Pamukkale University, Denizli.

\section{REFERENCES}

[1] Alver, E., Adıgüzel, T. \& Öztürk O. (2016). İstanbul'da 11 ayrı okul çeşidinde okul güvenliği araştırması. International Journal of Eurasia Social Sciences, 7 (23), 274-298.

[2] Bredenberg, K. \& Heeyit, Y. (2004). The Child-friendly Schools' movement and impacts on children's learning: Practical applications in Cambodia. Working Papers: Expanded Basic Education Program, Phnom Penh, Cambodia.

[3] Clair, N., Miske, S. \& Patel, D. (2012). Child rights and quality education: child-friendly schools in Central and Eastern Europe (CEE). European Education, 44(2), 5-22.

[4] Creswell, J. W. (2003). Research design. London: Sage Publication.

[5] The Convention of Children Rights (1989), UNICEF Turkey, 2004.

[6] Das, S. N. (2014). Do "child-friendly" practices affect learning? Evidence from Rural India. Working Paper No. 14-03, Department of Quantitative Social Science, Institute of Education, University of London.

[7] Değirmencioğlu S. M. (2012). Katılım hakkına tersten yaklaşım: Tersten katılım. Uluslararası Katılımlı Çocuk Ihtiyaçları Sempozyumu, Ankara, 18-19 Mayıs 2012.

[8] Dodson, C. K. (2005). The relationship between school effectiveness and teachers' job satisfaction in north Mississippi schools (Unpublished Doctoral Dissertation), Mississippi University, Oxford

[9] Erol, F. (2009). Okulda güvenlik sorununa yol açan etkenlerin belirlenmesi. Ankara: EARGED.

[10] Gray, C. \& Leith, H. (2004) Perpetuating gender stereotypes in the classroom: a teacher perspective. Educational Studies, 30 (1), 3-17, DOI: $10.1080 / 0305569032000159705$

[11] Hammarberg, T. (1998). A School for Children with Rights. UNICEF International Child Development Centre Piazza SS. Annunziata 12 - 50122 Florence, Italy ISBN 88-85401-36-8

[12] Harbaugh, R. J. (2005). Examining the correlates of effective schools present in an intermediate school: A case study (Unpublished Doctoral Dissertation), Immaculate University, Pennsylvania.

[13] Kahveci, G. \& Demirtaş, Z. (2012). İlköğretim Okulu 6., 7. ve 8 . sınıf ögrencilerinin temizlik ve hijyen algıları. Pegem Eğitim ve Öğretim Dergisi, 2 (2), 51-61.

[14] Kılıç A. Z. (2015). Katılımcı okul uygulamaları: Eğitimciler için el kitabı. İstanbul: İstanbul Bilgi Üniversitesi Yayınları. 
[15] Modipane, M., \& Themane, M. (2014). Teachers' social capital as a resource for curriculum development: lessons learned in the implementation of a Child-Friendly Schools programme. South African Journal of Education, 34(4), $1-8$.

[16] Nyatuka, B. O. (2015). Assessment of the effectiveness of family-school-community partnership in Kenya's child-friendly schools. (Unpublished Doctoral Dissertation), University of South Africa.

[17] Orkodashvili, M. (2013). Quality education through child-friendly schools: resource allocation for the protection of children rights. Revista Romaneasca Pentru Educatie Multidimensional, 5 (1), 101-109.

[18] Osher, D., Kelly, D. L., Tolani-Brown, N., Shors, L., \& Chen, C. S. (2009). UNICEF child-friendly schools programming: Global evaluation final report. Washington, DC: American Institutes for Research.

[19] Özcan C., Kılınç S. \& Gülmez H. (2013). Türkiye'de okul sağlı̆̆ı ve yasal durum. Ankara Medical Journal, 13(2), 71-81.

[20] Özcebe H. (2012). Okul sağlığı hizmetlerinde mevcut durum ve model beklentisi. II. Ulusal Okul Să̆llğ Sempozyumu Bildiri Kitabl, 17-18 Mayıs 2012, Adana.Reimer, J. K. (2012). Local negotiation of globalized educational discourses: the case of child-friendly schools in rural Cambodia.

[21] Redding, S. (1997). Parents and learning, educational practices Series 2, International Academy of Education, Brussels (Belgium). International Bureau of Education Publication, Geneva (Switzerland) Eric ED:463858

[22] UNICEF (2009). Child-friendly schools manual. New York: UNICEF.

[23] UNICEF (2012). Child - Friendly Schooling Approach. Retrieved from https://www.unicef.org/education/bege_61717.html.

[24] UNICEF/UNESCO. (2007). A human rights-based approach to education for all. New York: UNICEF.

[25] Yiğit, B. \& Bayrakdar, M. (2006). Okul-çevre ilişkileri. Ankara: Pegem A Yayıncilık.

[26] Younger, M. \& Warrington, M. (1996) Differential achievement of girls and boys at GCSE: some observations from the perspectives of one school. British Journal of Sociology of Education, 17, 299-314.

[27] Reimer, J. K. (2012). Local negotiation of globalized educational discourses: the case of child friendly schools in rural Cambodia. (Unpublished Doctoral Dissertation) The University Of British Columbia, Vancouver, Canada. 